\title{
Effect of Moderate Pressure Treatments on Microstructure, Texture, and Sensory Properties of Stirred-Curd Cheddar Shreds
}

\author{
J. Serrano, ${ }^{1,2}$ G. Velazquez, ${ }^{1,3}$ K. Lopetcharat, ${ }^{4}$ J. A. Ramírez, ${ }^{3}$ and J. A. Torres ${ }^{1}$ \\ ${ }^{1}$ Food Process Engineering Group, Department of Food Science and Technology, \\ Oregon State University, 100 Wiegand Hall, Corvallis 97331-6602 \\ ${ }^{2}$ Dpto. de Investigación y Posgrado en Alimentos, Facultad de Química, \\ Universidad Autónoma de Querétaro, Centro Universitario, \\ Cerro de las Campanas, 76010 Querétaro, QRO, México \\ ${ }^{3}$ Department of Food Science and Technology, U. A. M. Reynosa-Aztlán, \\ Universidad Autónoma de Tamaulipas, Apdo. Postal 1015, Reynosa, Tam. 88700 México \\ (Mail address in USA: PMB 374, 501 N. Bridge St., Hidalgo, TX 78557) \\ ${ }^{4}$ Unilever Research-US, 45 River Road, Edgewater, NJ 07020
}

\begin{abstract}
A moderate high-pressure processing (HPP) treatment is proposed to accelerate the shredability of Cheddar cheese. High pressure processing ( 345 and $483 \mathrm{MPa}$ for 3 and $7 \mathrm{~min}$ ) applied to unripened (1 d old) stirredcurd Cheddar cheese yielded microstructure changes that differed with pressure level and processing time. Untreated and pressure-treated cheese shredded at $d$ 27 and 1, respectively, shared similar visual and tactile sensory properties. The moderate $(345 \mathrm{MPa})$ and the higher $(483 \mathrm{MPa})$ pressure treatments reduced the presence of crumbles, increased mean shred particle length, improved length uniformity, and enhanced surface smoothness in shreds produced from unripened cheese. High-pressure processing treatments did not affect the mechanical properties of ripened cheese or the proteolytic susceptibility of milk protein. It was concluded that a moderate HPP treatment could allow processors to shred Cheddar cheese immediately after block cooling, reducing refrigerated storage costs, with expected savings of over $15 \mathrm{US} \$ / 1000 \mathrm{lb}$ cheese, and allowing fewer steps in the handling of cheese blocks produced for shredding.
\end{abstract}

(Key words: Cheddar cheese, high-pressure processing, microstructure, shredability)

Abbreviation key: HPP = high-pressure processing, NPN = nonprotein nitrogen, $\mathbf{S E M}=$ scanning electron microscopy, $\mathbf{T N}=$ total nitrogen, $\mathbf{T P A}=$ texture profile analysis, $\mathbf{W S N}=$ water-soluble nitrogen .

\section{INTRODUCTION}

Cheddar cheese is the most widely consumed cheese in the United States. It is a multifunctional ingredient,

Received February 9, 2004.

Accepted May 15, 2004.

Corresponding author: J. A. Torres; e-mail: J_Antonio.Torres@ oregonstate.edu. with shredding used by cheese manufacturers to market a value-added product. The same interest in shredded cheese has been observed elsewhere in the world. Shredded Cheddar cheese and other natural cheeses add unique flavor notes to pizzas, salads, and many other recipes. The high cheese production volumes and low prices currently observed in the United States have forced dairy producers to seek alternatives reducing the cost of shredded Cheddar cheese, while at the same time improving quality. Many cheeses could be shredded commercially, but cold-storage costs before a cheese can be shredded are often an economic barrier in furthering market growth. Cheddar cheese requires about $30 \mathrm{~d}$ of ripening before shredding, adding refrigerated storage and handling costs to the product. Key attributes improved by ripening include the reduction of crumbs and improvements in surface smoothness, shred mean length, and size uniformity. Other desirable attributes improved by ripening are shred-to-shred piece adhesiveness, visual perception of oiliness, and tactile oiliness after shred handling (McMahon, personal communication, 2001).

Two manufacturing technologies are used in Cheddar cheese production. In traditional or milled-curd technology, blocks of about 25-cm height are piled on top of each other, allowed to rest for about $15 \mathrm{~min}$, and then turned over. This procedure (cheddaring) is repeated 2 or 3 times to reach the desired curd acid level. In the more recently developed stirred-curd approach, curd is not cheddared; instead, drained curd is agitated continuously to reach the desired acid level. The constant agitation of the curd does not allow knitting of curd particles, but the Cheddar cheese obtained has similar composition and properties. Stirred-curd technology is simpler to mechanize than the traditional method (Williams, 1997).

The microstructure of Cheddar cheese can be described as a continuous protein matrix, creating a po- 
rous structure with spaces occupied by fat globules distributed in the casein network (Bryant et al., 1995). The casein network depends on chemical composition, manufacturing process, proteolysis during ripening, and the size and distribution of the fat globules (Lagoueyte et al., 1994; Metzger and Mistry, 1995; Bryant et al., 1995; Sutheerawattananonda et al., 1997). Torres-Mora et al. (1996) were first in observing that highpressure treatments $(275 \mathrm{MPa}$ for $100 \mathrm{~s}$ ) applied to fresh curd immediately yielded a microstructure similar to aged Cheddar cheese, a finding that was later confirmed by Yang (1999).

Many publications describe microstructure and cheese composition effects on the mechanical and textural properties of cheese (e.g., Lee et al., 1978; Charalambides et al., 1995; Hort and LeGrys, 2000). Nienaber et al. (2000) subjected stirred-curd Cheddar cheese to hydrostatic pressure ranging from 100 to $800 \mathrm{MPa}$ (5 min, $25^{\circ} \mathrm{C}$ ) at different times during ripening. Pressuretreated cheese samples and controls showed a gradual decline in hardness, cohesiveness, gumminess, and chewiness over storage time. Pressurization at $400 \mathrm{MPa}$ resulted initially in hardness reduction, but after 10 wk of storage, hardness, cohesiveness, gumminess, and chewiness of the pressurized cheeses were not different from controls. However, the $800-\mathrm{MPa}$ treated cheese had higher hardness, cohesiveness, gumminess, and chewiness than the controls. Saldo et al. (2000a, 2000b) and Jin and Harper (2002) suggested that high-pressure processing (HPP) accelerates ripening by increasing moisture retention, releasing bacterial enzymes, and increasing enzyme activity while the cheese is under pressure. However, the effect of pressure treatments on aging has been reported to depend on pressure conditions and cheese variety (Messens et al., 1999, 2000; Saldo et al., 2000a).

The growth in shredded Cheddar cheese consumption provides the main justification for this work, and thus the central objective of this study was to determine the feasibility of using HPP to eliminate or reduce the ripening time needed before Cheddar cheese reaches shredability. This had to be achieved without deleteriously affecting the attributes of cheese shreds. Relatively little information has been published on the mechanical properties making cheese blocks suitable for shredding (Apostolopoulos and Marshall, 1994). Also absent in the published literature was a definition of sensory methods that processors could use in the development of consumer-acceptable shredded cheeses. This required developing a sensory evaluation methodology for shredded cheese and the examination of the microstructure and mechanical properties of pressuretreated cheese. Changes in sensory attributes by HPP may be associated with protein pressure-induced dena- turation and aggregation and changes in proteolytic enzymes. Thus, this study included determination of mechanical, microstructure, and biochemical properties to explain changes induced by pressure treatments and storage time on the sensory properties of shredded pressure-treated cheese.

\section{MATERIALS AND METHODS}

\section{Cheese Samples}

Fresh cow's milk stirred-curd Cheddar cheese blocks $(18.2 \mathrm{~kg}$ ) provided by Glanbia Foods Inc. (Twin Falls, ID) were collected immediately after cooling and transported refrigerated for pressure processing at the facilities of Avure Technologies, Inc. (Kent, WA). Blocks were cut into small blocks $(7 \times 3.5 \times 18 \mathrm{~cm})$ and vacuumpacked for treatments at 345 and $483 \mathrm{MPa}$ for 3 and 7 min within $24 \mathrm{~h}$ of sample collection. Untreated and pressure-treated cheese was placed in storage for ripening at $7^{\circ} \mathrm{C}$ for further analysis.

\section{Chemical Analysis of Cheese}

Pressure-treated and untreated cheese samples were analyzed in triplicate after $1,6,13$, and $27 \mathrm{~d}$ of ripening for moisture, protein, fat, sodium, and $\mathrm{pH}$ (Marshall, 1992). Proteolysis throughout storage was monitored using the microKjeldahl method (AOAC, 2000) by measuring total nitrogen (TN), water-soluble nitrogen at pH 4.6 (WSN), and nonprotein nitrogen (NPN) measured after removing proteins with a $12 \%$ TCA solution.

\section{Texture Analysis}

Cubes of $20 \mathrm{~mm}$, cut using a custom-designed wire cutter to obtain samples of uniform shape and size, were kept in sealed plastic bags to avoid surface drying. Cut samples were held at $4^{\circ} \mathrm{C}$ for $12 \mathrm{~h}$ before performing compression tests using a TA.XT2 Texture Analyzer (Stable Micro Systems, UK). Texture profile analysis (TPA) at $50 \%$ was performed at $1 \mathrm{~mm} / \mathrm{s}$ of crosshead speed with a $25-\mathrm{kg}$ load cell and $50-\mathrm{mm}$ diameter aluminum probe (model P/50). Ten samples for each treatment were analyzed after $1,6,13$, and $60 \mathrm{~d}$ of ripening to calculate hardness, springiness, and cohesiveness values. Equipment availability required the change in the last sampling day for texture analysis.

\section{Scanning Electron Microscopy}

Scanning electron microscopy (SEM) analysis was carried out at the OSU Electron Microscopy laboratory. Small pieces ( 2 to $3 \mathrm{~mm}$ ), collected $1 \mathrm{~d}$ after pressure treatment, were chemically fixed with glutaraldehyde 
buffer in refrigerated glass vials. The fixative reagent was then removed and samples were washed for $24 \mathrm{~h}$ with $0.0125 M$ pH 7.2 cacodylate buffer, transferred into $1 \%$ osmium tetroxide in fresh cacodylate buffer for $48 \mathrm{~h}$, then passed through 50 and $70 \%$ ethanol/water solutions and washed twice with $100 \%$ ethanol with a minimum of $4 \mathrm{~h}$ per change. Each sample was then placed in an aluminum weighing pan containing liquid nitrogen. Fully frozen samples were pressure fractured, with the resulting pieces collected into biopsy bags (Fisher Scientific 15 to 182 to $506 \mathrm{H}$ ), stored in absolute ethanol, and then critical-point dried (Anderson, 1951, 1966; DeBault, 1973). Under stereo light microscopy, small pieces of thoroughly fixed fractured cheese were mounted on aluminum planchettes with the fractured surfaces upward and then coated with $200 \mathrm{~nm}$ of 60/40 wt \% Au/Pd alloy in a Varian VE-10 vacuum evaporator (Varian, Inc. Vacuum Technologies, Lexington, MA).

\section{Sensory Analysis}

A descriptive sensory analysis (Lawless and Heymann, 1998; Meilgaard et al., 1999) was performed by a trained panel consisting of 9 subjects (4 males and 5 females) from the OSU Department of Food Science and Technology. During training, panelists were asked to identify and define visual appearance and tactile properties characterizing shredded cheese. Panelists were presented with an array of commercial shredded cheese samples to aid in the development of these terms. Descriptors selected for appearance were visual oiliness, surface smoothness, shred mean length, uniformity of shred length, and amount of crumbles. Other terms selected by the panel were tactile oiliness and shred adhesiveness (Table 1). Panelists marked responses on a 9-point intensity scale anchored with "not" on the left and "very" on the right ends of the scale. Panelists were trained for 2 wk in 6 sessions of $1 \mathrm{~h}$; in the first 2 sessions, the panel determined the terminology and the definition of the 7 descriptors; in the following 2 sessions, panelists suggested standards and also scored them; and the final 2 sessions were used for practice sessions with commercial and pressure-treated samples. All panelists were monetarily compensated for their participation in the study.

During the sensory analysis of experimental samples, panelists evaluated 10 samples per session. Cheeses were shredded using a food processor (Hobart Corp. Troy, OH, model A200) with a front-mounted taper attachment hub (model VS9) and adjustable shredder plate (3/16", model VS9). Then $5 \mathrm{~g}$ of cheese was presented in 3-digit random coded plastic sample cups (50 $\mathrm{mL}$ ) covered with lids to avoid surface drying and held in a constant temperature $\left(4^{\circ} \mathrm{C}\right)$ for at least $2 \mathrm{~h}$ before sensory analysis. For sample evaluation, the panelist poured the cup into $15.2-\mathrm{cm}$ diameter white foam plates, with testing performed under white fluorescent light. Napkins were provided to cleanse hands between samples, which was mandatory for panelists. Sample presentation order was randomized across sessions and judges, with sample evaluations conducted at $1,6,13$, and $27 \mathrm{~d}$ after pressure treatment.

\section{Statistical Analysis}

All data were analyzed by multivariate ANOVA (MANOVA) using SPSS v.10 (SPSS Inc., Chicago, IL) to inspect the effect of pressure, process time, and storage on the attributes measured instrumentally and sensorially with 2 replications. Significance differences for least square means were determined at $95 \%$ significance level. The same software was used to conduct principal component analysis to identify experimental groups.

\section{RESULTS AND DISCUSSION}

\section{Cheese Proximate Analysis}

Chemical composition determined at 1, 13, and $27 \mathrm{~d}$ showed that moisture (38 to $38.1 \%$ ), fat (33.1 to $33.5 \%$ ), protein (35.1 to $37.5 \%$ ), and sodium (194.2 to $199.3 \mathrm{mg} /$ $\mathrm{kg}$ ) contents were not significantly different among the pressure treatments and did not change with storage time. Similar results were obtained by Capellas et al. (2001), who reported that 100 to $400 \mathrm{MPa}$ treatments did not alter total solids, ashes, fat, and soluble nitrogen.

\section{Sensory Analysis}

Values for the sensory descriptors used by the trained panel (Table 1) to evaluate shredded samples from untreated and pressure-treated cheese are summarized in Figure 1. Pressure level, pressure-holding time, and storage significantly affected the shred mean length of all samples. Storage time had more effect on the shred mean length values of untreated samples (controls), which increased with storage (scored 4.8 to 5.7); however, storage time had less effect on pressure-treated samples (Figure 1a). Pressure level in conjunction with processing time affected the mean length of shreds from treated cheese. Pressure-treated samples had longer mean length than controls stored up to $6 \mathrm{~d}$ when the shred mean length of treated and control samples were comparable.

Pressure treatments had an obvious effect on the length uniformity of shreds (Figure 1b). Untreated cheese (scored 2.3 to 4.7 ) yielded shreds that had less 
Table 1. Definition of the sensory attributes for shredded Cheddar cheese

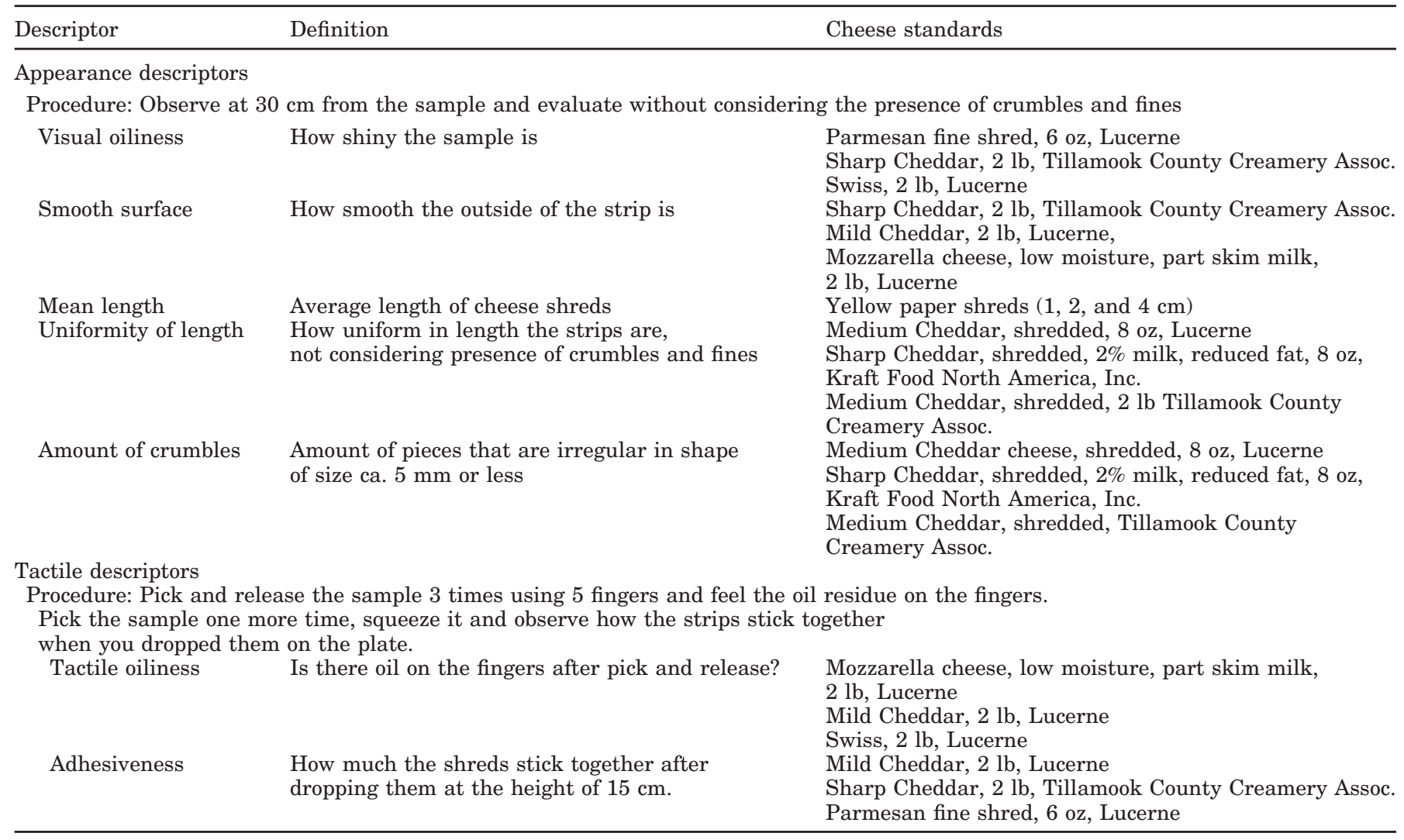

uniform length when compared with shreds from pressure-treated samples (scored 5.0 to 6.6). In addition, pressure-holding time and storage affected differences between samples, and these effects depended on pressure level. However, differences in shred length uniformity caused by pressure level, pressure time, and storage time were smaller among treated samples (1.6 units difference) compared with differences between treated and untreated samples (4.3 units difference). The length uniformity of untreated samples increased during storage, while in pressure-treated samples it decreased slightly and became stable during storage. During storage of shreds from treated cheese, changes in length uniformity differed depending on pressure treatment conditions.

Only pressure level and storage time significantly influenced changes in the amount of crumbles of the shred (Figure 1c). Moreover, the effects of pressure level and storage time were independent of each other. The panel detected a lower amount of crumbles at the higher pressure level and at longer storage times. Untreated samples had the highest amount of crumbles at $d 1$ (scored 7.5), then reduced to a stable level (scored $\sim 4$ ) after $13 \mathrm{~d}$ of storage. In contrast, shreds from pressuretreated samples had the lowest amount of crumbles at d 1, with values of $\sim 2.3$ for $483 \mathrm{MPa}$ and $\sim 2.8$ for 345 $\mathrm{MPa}$ treated cheese; the amount increased slightly at $\mathrm{d} 6$ and then tended to decrease until d 27 .

Adhesiveness of shreds was affected by pressure level, pressure-holding time, and storage, and the interaction effect between these factors was significant (Figure 1d). Shreds from untreated cheese tended to possess higher adhesiveness than pressure-treated cheese. Unlike other attributes, shred adhesiveness did not converge at d 27. Visual oiliness of shred also depended on all 3 factors and tended to converge after $6 \mathrm{~d}$ of storage (Figure 1e). At d 1, the effect of pressure level and pressure-holding time was pronounced. Shreds from untreated cheese had the lowest visual oiliness (scored 2.2), followed by those subjected to $345 \mathrm{MPa}$ (scored 2.9 to 3.3), while $483 \mathrm{MPa}$-treated shreds had the highest values (scored 3.3 to 4.0 ). The effect of processing time was significant in $483 \mathrm{MPa}$-treated samples at $d 1$ with shreds from 3-min treated cheese, with lower visual oiliness (scored 2.8 to 4.0 ) than those from 7-min treated cheese (scored 3.3 to 3.8).

Values for tactile oiliness were significantly different among all samples (Figure 1f). The values for shreds from untreated cheese increased with storage, changing from 3.0 at $d 1$ to 3.8 at $d 27$. Regardless of 


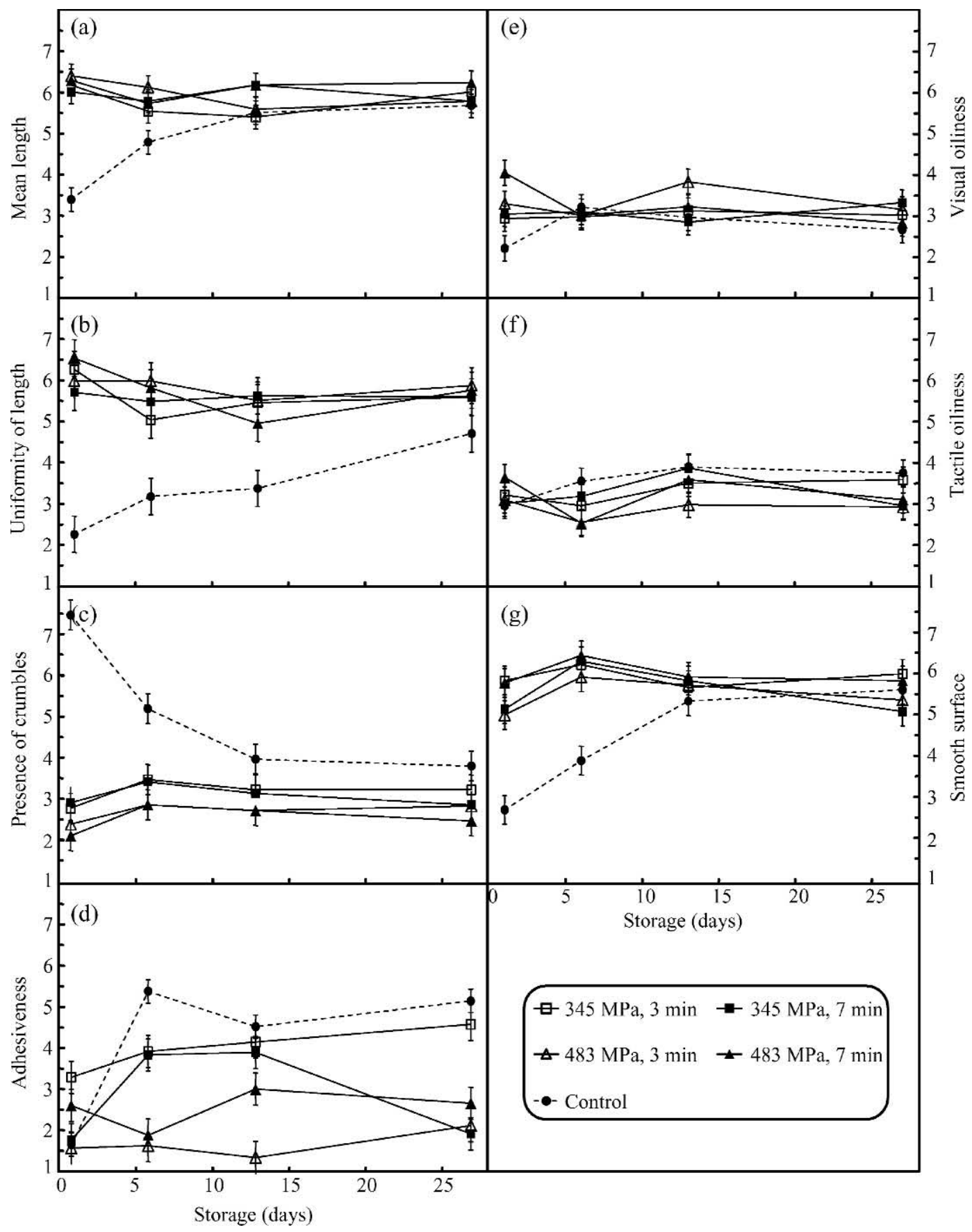

Figure 1. Sensory profiles of shredded pressure-treated and control stirred curd Cheddar cheese.

pressure level, shreds from pressure-treated cheese had lower tactile oiliness at d 6, increasing at d 13 and stabilizing at $\mathrm{d} 27$. Pressure-holding time affected tactile oiliness differently in cheese treated at different pressure levels and led to different behavior during storage. Overall, samples from $345 \mathrm{MPa}$-treated cheese tended to have higher tactile oiliness than samples treated at $483 \mathrm{MPa}$ regardless of storage time. At longer pressure-holding times, higher tactile oiliness values were detected regardless of storage time.

Pressure-treated samples yielded shreds with smoother surface than those from untreated samples; however, no differences in the smoothness of the shred surface were observed at $d 27$ (Figure $1 \mathrm{~g}$ ). The smoothness of shred surface of untreated cheese increased during storage time, changing from 2.8 at $\mathrm{d} 1$ to 5.7 


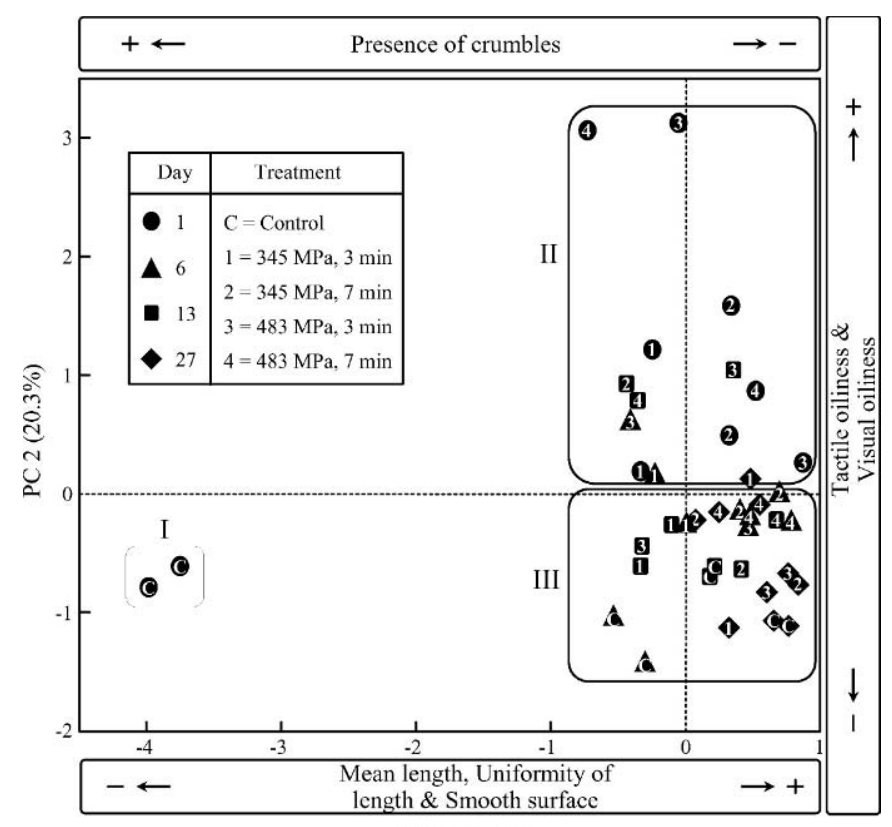

PC $1(59.0 \%)$

Figure 2. Principal component analysis for the pressure effect on the sensory properties of stirred curd Cheddar cheese.

at $\mathrm{d} 27$. On the other hand, the smoothness of shreds from treated cheese increased from 5.2 to 5.8 at d 1 to 3.9 to 6.2 at d 6 and then decreased or stabilized depending on pressure level and pressure-holding time (scored 5.7 to 6.2 ).

Correlation between sensory descriptors was summarized using principal component analysis, which identified 3 groups of samples (I to III). There were 2 major dimensions extracted from the data that described the samples in these groups (Figure 2). The PC1 dimension took into account $52.4 \%$ of the variance, and comprised mean length, uniformity of length, shred smooth surface, visual oiliness, and presence of crumbles. Presence of crumbles was negatively correlated with the other attributes in the shred-dimension. The PC2 dimension took into account $23.8 \%$ of the varinace and it comprised tactile oiliness and adhesiveness, which were positively correlated (Fig. 2). Group I included d 1 controls characterized by high values for the amount of crumbles and the low values for visual and tactile oiliness, smooth surface, adhesiveness, shred mean length and shred length uniformity. Reflecting the ripening effect, group II included the control for d 6, 13, and 27, and was characterized by a higher shred to shred particle adhesion, smooth surface, shred mean length and uniformity, visual oiliness, and lower amount of crumbles. Also included in this group, and reflecting the effect of HPP treatments, were samples $345 \mathrm{MPa} / 3 \mathrm{~min}$ for d 6, 13, and 27, $345 \mathrm{MPa} / 7$ min for d 6 and 13, and $483 \mathrm{MPa} / 7 \mathrm{~min}$ for $\mathrm{d} 1,13$, and 27 . Group III corresponded to $345 \mathrm{MPa} / 3 \mathrm{~min}$ for d 1, $345 \mathrm{MPa} / 7 \mathrm{~min}$ for d 1 and 27, $483 \mathrm{MPa} / 3 \mathrm{~min}$ for all sampling days, and $483 \mathrm{MPa} / 7 \mathrm{~min}$ for $\mathrm{d} 6$. These samples were characterized by a lower shred-to-shred particle adhesion and lower tactile oiliness, but were otherwise similar to those in group II.

\section{Texture Profile Analysis}

Parameters calculated from TPA analysis for control and pressure-treated Cheddar cheese samples are shown in Table 2. During storage, the hardness of control samples decreased. The HPP treatment increased hardness at $d 1$ with an effect increasing with pressure level and pressurization time (Table 2). The hardness values of cheese samples pressurized $3 \mathrm{~min}$ at 345 and $483 \mathrm{MPa}$ were not different but were significantly higher than those for untreated samples $(P$ $<0.05$ ). Similarly, samples treated $7 \mathrm{~min}$ at 345 or 483 MPa were not different, but had significantly higher values than untreated samples and those pressure treated for $3 \mathrm{~min}$. The hardness of all pressure-treated samples decreased significantly during the remaining $60 \mathrm{~d}$ of storage. Samples treated for 3 min were not different from d-60 untreated samples, while samples treated for $7 \mathrm{~min}$ were softer or harder than the control when treated at 345 or $483 \mathrm{MPa}$, respectively. Springiness changed during the first $13 \mathrm{~d}$ of storage, decreasing significantly at d 60 for untreated cheese (Table 2). At d 1, HPP samples had springiness values slightly higher than untreated samples, with only 7-min treated samples significantly $(P<0.05)$ higher than control. During storage, springiness decreased for 345$\mathrm{MPa}$ pressure-treated samples, reaching the lowest values at $\mathrm{d} 60$, but did not for the $483-\mathrm{MPa}$ treated samples. All treated samples showed higher springiness values than untreated samples, with the 483MPa treated samples reaching the highest values. The cohesiveness of untreated samples decreased during storage, reaching the lowest values at d 60 (Table 2). All treated samples showed differences at d 1 only when compared with untreated samples. During ripening, the cohesiveness values of all pressure-treated cheese samples were lower at d 60, but were still significantly higher than untreated samples, and with no differences between pressure treatments.

\section{Scanning Electron Microscopy}

The functional and mechanical properties of cheese reflect its microstructure, which is a continuous protein matrix with fat globules dispersed in the protein 
Table 2. Effect of pressure treatments and ripening time on texture profile analysis parameters.

\begin{tabular}{|c|c|c|c|c|c|c|}
\hline \multirow{2}{*}{$\begin{array}{l}\text { Texture } \\
\text { parameter }\end{array}$} & \multirow{2}{*}{$\begin{array}{l}\text { Storage } \\
\text { (d) }\end{array}$} & \multirow[b]{2}{*}{ Control } & \multicolumn{2}{|c|}{$345 \mathrm{MPa}$} & \multicolumn{2}{|c|}{$483 \mathrm{MPa}$} \\
\hline & & & $3 \min$ & $7 \mathrm{~min}$ & $3 \min$ & $7 \mathrm{~min}$ \\
\hline Hardness (kg) & $\begin{array}{r}1 \\
6 \\
13 \\
60\end{array}$ & $\begin{array}{l}13.2^{\mathrm{a}, 1} \\
14.3^{\mathrm{a}, 1} \\
12.3^{\mathrm{a}, \mathrm{b}, 1} \\
11.3^{\mathrm{b}, 1}\end{array}$ & $\begin{array}{l}15.4^{\mathrm{a}, 2} \\
14.2^{\mathrm{b}, 1} \\
10.5^{\mathrm{c}, 2} \\
10.7^{\mathrm{c}, 1}\end{array}$ & $\begin{array}{r}16.9^{\mathrm{a}, 3} \\
13.0^{\mathrm{b}, 2} \\
11.0^{\mathrm{c}, 2} \\
9.8^{\mathrm{d}, 2}\end{array}$ & $\begin{array}{l}15.0^{\mathrm{a}, 2} \\
14.2^{\mathrm{a}, 1} \\
17.7^{\mathrm{b}, 1} \\
11.0^{\mathrm{c}, 1}\end{array}$ & $\begin{array}{l}17.0^{\mathrm{a}, 3} \\
14.9^{\mathrm{b}, 1} \\
12.8^{\mathrm{c}, 3} \\
13.2^{\mathrm{c}, 3}\end{array}$ \\
\hline Springiness & $\begin{array}{r}1 \\
6 \\
13 \\
60\end{array}$ & $\begin{array}{l}0.75^{\mathrm{a}, 1} \\
0.70^{\mathrm{b}, \mathrm{c}, 1} \\
0.72^{\mathrm{a}, \mathrm{b}, 1} \\
0.67^{\mathrm{c}, 1}\end{array}$ & $\begin{array}{l}0.77^{\mathrm{a}, 1,2,3} \\
0.76^{\mathrm{a}, \mathrm{b}, 2} \\
0.75^{\mathrm{a}, \mathrm{b}, 1,2} \\
0.73^{\mathrm{b}, 2,3}\end{array}$ & $\begin{array}{l}0.81^{\mathrm{a}, 3} \\
0.76^{\mathrm{b}, 2} \\
0.75^{\mathrm{b}, 1,2} \\
0.71^{\mathrm{c}, 2,3}\end{array}$ & $\begin{array}{l}0.77^{\mathrm{a}, 1,2,3} \\
0.79^{\mathrm{a}, \mathrm{b}, 2} \\
0.82^{\mathrm{b}, 3} \\
0.76^{\mathrm{a}, 3,4}\end{array}$ & $\begin{array}{l}0.79^{\mathrm{a}, 2,3} \\
0.78^{\mathrm{a}, 2} \\
0.77^{\mathrm{a}, 2} \\
0.78^{\mathrm{a}, 4}\end{array}$ \\
\hline Cohesiveness & $\begin{array}{r}1 \\
6 \\
13 \\
60\end{array}$ & $\begin{array}{l}0.42^{\mathrm{a}, 1} \\
0.44^{\mathrm{a}, 1} \\
0.44^{\mathrm{a}, 1} \\
0.38^{\mathrm{b}, 1}\end{array}$ & $\begin{array}{l}0.48^{\mathrm{a}, 1} \\
0.48^{\mathrm{a}, 2} \\
0.48^{\mathrm{a}, 2} \\
0.43^{\mathrm{b}, 1}\end{array}$ & $\begin{array}{l}0.51^{\mathrm{a}, 2} \\
0.48^{\mathrm{a}, 2} \\
0.48^{\mathrm{a}, 2} \\
0.43^{\mathrm{b}, 1}\end{array}$ & $\begin{array}{l}0.50^{\mathrm{a}, 2} \\
0.50^{\mathrm{a}, 2} \\
0.50^{\mathrm{a}, 2} \\
0.46^{\mathrm{b}, 3}\end{array}$ & $\begin{array}{l}0.51^{\mathrm{a}, 2} \\
0.50^{\mathrm{a}, 2} \\
0.49^{\mathrm{a}, 2} \\
0.45^{\mathrm{b}, 2,3}\end{array}$ \\
\hline
\end{tabular}

a,b,c, Mean values $(\mathrm{n}=8)$ in column with different superscript letters differ $(P<0.05)$

${ }^{1,2}$ Mean values $(\mathrm{n}=8)$ in rows with different superscript numbers $\operatorname{differ}(P<0.05)$.

network (Bryant et al., 1995; Rosenberg et al., 1995). The network structure determines cheese texture and is affected by composition, manufacturing process, proteolysis during ripening, and fat droplet size and distribution (Lagoueyte et al., 1994; Torres-Mora et al., 1996; Sutheerawattananonda et al., 1997). The microstructure of 1-d-old untreated and pressuretreated Cheddar cheese, as observed by scanning electron microscopy, is shown in Figure 3. The control cheese presented a porous protein network, prominent clumping, and sponge-like appearance, with fat globules of different size and shape distributed nonuniformly.

Guinee et al. (2000) reported that in Cheddar cheese fat is distributed in the casein network as discrete fat droplets or large irregular sections, which coincides with the control cheese observations reported here. The microstructure of pressure-treated cheese, however, showed a polymer network with an instant microstructure change to continuous protein matrices resembling aged Cheddar cheese. This effect was observed to a different extent depending on the pressure level and process time of the HPP treatment. Changes in microstructure were highest for $483 \mathrm{MPa} / 7 \mathrm{~min}$ treatment, followed by $483 \mathrm{MPa} / 3 \mathrm{~min}, 345 \mathrm{MPa} / 7$ $\min$, and $345 \mathrm{MPa} / 3$ min treatments. Cheese treated at $483 \mathrm{MPa}$ for $7 \mathrm{~min}$ had the most continuous microstructure, while the protein matrices observed in samples treated at $345 \mathrm{MPa}$ for 3 and 7 min showed sections with the sponge-like appearance, while others exhibited a smooth, continuous protein network.

\section{Changes in pH}

The $\mathrm{pH}$ of the control cheese samples increased during storage. The initial $\mathrm{pH}$ increase induced by pres- sure treatments (Figure 4a) reflected a stronger effect of pressurizing time than pressure level, with $7 \mathrm{~min}$ $>3$ min $>$ control. During storage, $\mathrm{pH}$ showed fluctuations, but at $\mathrm{d} 27$, the difference in $\mathrm{pH}$ between HPP samples and untreated control was minimal. Messens et al. (1999) reported a $\mathrm{pH}$ shift of about 0.25 units 1 $\mathrm{d}$ after $400 \mathrm{MPa}$ was applied for $6 \mathrm{~min}$ in Gouda cheese; they associated it with both a reduction in microbial activity to convert lactose to lactic acid and enhanced proteolysis. Casal and Gomez (1999) found a reduction in acidifying activity in lactic acid cultures after HPP treatment, even though there was no apparent loss of cell viability. On the other hand, Saldo et al. (2000a) reported about 3 log cycles reduction in starter counts after a $400-\mathrm{MPa}$ treatment, which was interpreted as the cause for a higher final $\mathrm{pH}$. In the work here reported, initial $\mathrm{pH}$ differences between controls and pressure-treated samples decreased to a minimum during storage, suggesting only minor effects of HPP treatments on global microbial and proteolytic activity.

\section{Nonprotein Nitrogen}

All pressure-treated samples showed an increase in NPN/TN (Figure 4b) and WSN/TN (Figure 4c) values during storage. Pressure level and time significantly influenced the development of NPN/TN during the 27 d of storage (Figure 4b). At d 27, control and 3-min HPP samples showed a significantly lower NPN/TN level when compared with samples treated at 385 and $483 \mathrm{MPa}$ for $7 \mathrm{~min}$. These results suggest that although the HPP treatments modified cheese microstructure (Figure 3), mechanical properties (Table 2), and visual and tactile sensory parameters (Figures 1 and 2), significant proteolytic activity occurred during 


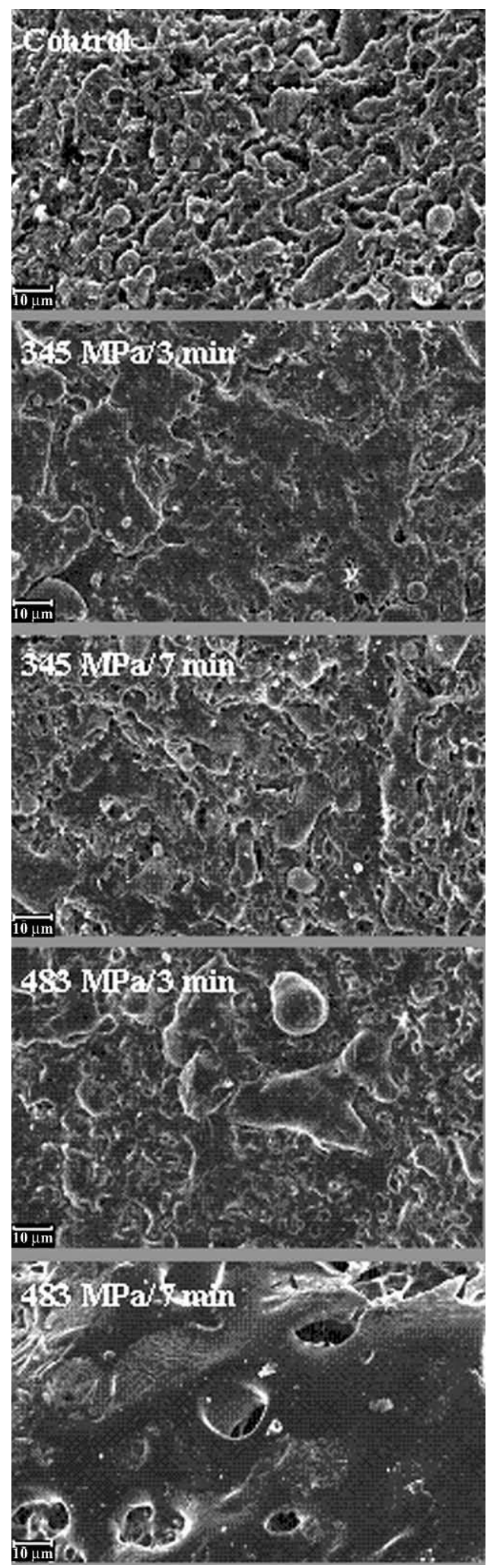

Figure 3. Scanning electron microscopy micrographs of pressuretreated and control stirred-curd Cheddar cheese (1000× magnification, bar represents $10 \mu \mathrm{m}$ ).

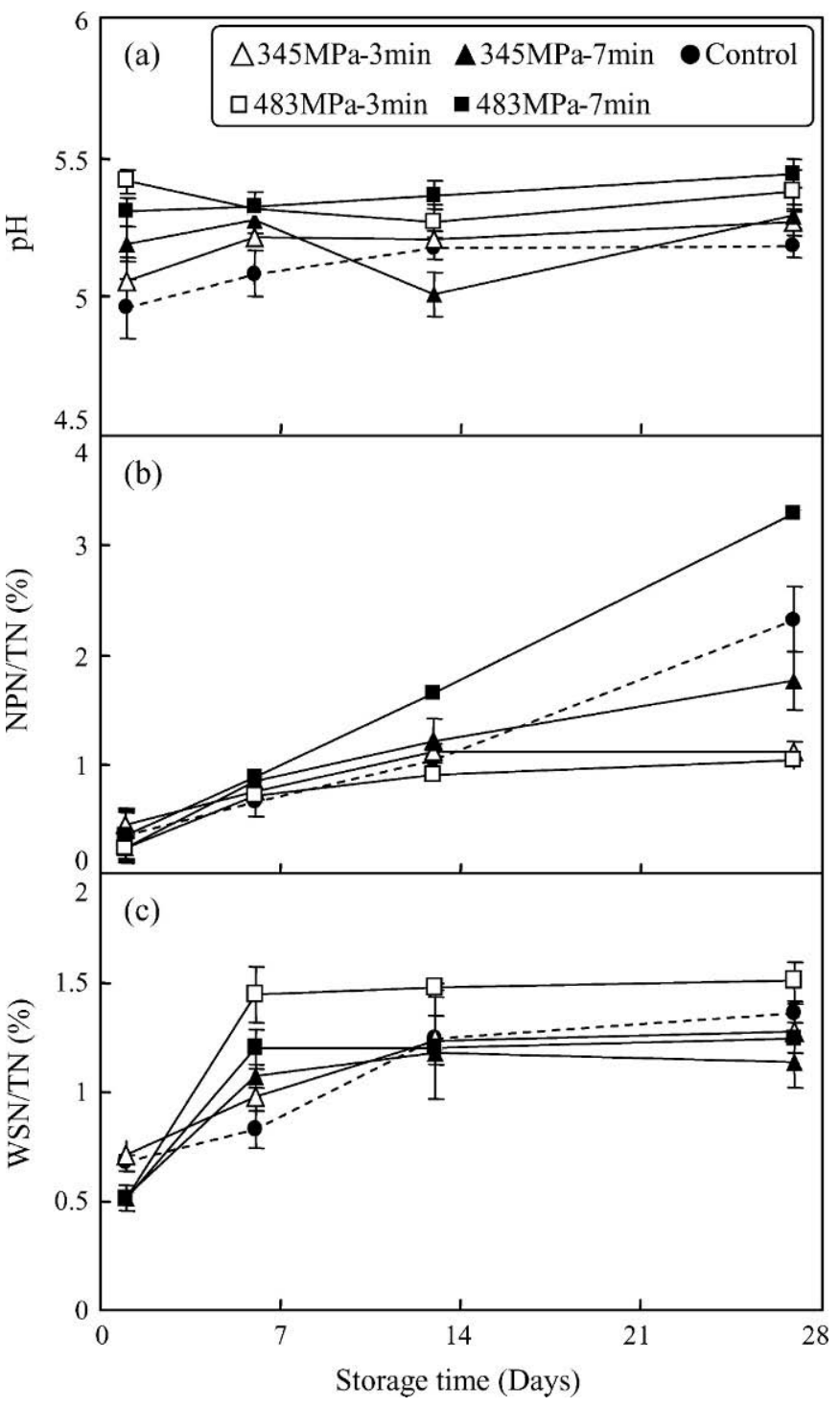

Figure 4. Effects of pressure treatment and ripening time on $\mathrm{pH}$ (a), nonprotein nitrogen (b) and water soluble nitrogen (c) during ripening of stirred-curd Cheddar cheese.

storage for both control and treated samples, with some treatments showing higher NPN/TN values. Smit et al. (1996) found a higher peptidolytic activity in pressurized starter cultures and associated it with an increase in cell lysis enhancing membrane permeability and the release of proteolytic enzymes into the cheese.

Casal and Gomez (1999) pointed out that the pressure-treated cells of some Lactococcus and Lactobacillus exhibited a greater hydrolytic activity on the Cpeptide than untreated controls. These events could contribute to the release of small protein fractions and free amino acids due to microbial enzymes activity 
increasing NPN values (Fox, 1988). It is also important to consider that most starter peptidases have an optimal $\mathrm{pH}$ higher than observed in the control cheese (Visser, 1993), and thus the increase in $\mathrm{pH}$ of 345 and $483 \mathrm{MPa}$ treatments could reflect increased enzymatic activity. Messens et al. (1999) reported that $300 \mathrm{MPa} / 50$ min pressure treatments disrupted the paracasein network, leading to a higher amount of peptides. However, in the study here reported, the experimental design covered much shorter pressure treatment times.

\section{CONCLUSIONS}

The effect of HPP treatments on the shredability of Cheddar cheese manufactured by conventional milledcurd technology (Serrano, 2003) has been shown to be similar to that reported here for Cheddar cheese manufactured by the stirred-curd approach. This observation suggests that pressure treatments could improve the early shredability of other natural cheeses of commercial interest, but this prediction should be evaluated experimentally. The use of pressure processing technology would reduce manufacturing costs of shredded cheese by eliminating cheese handling steps and reducing refrigerated storage currently required before shredding of Cheddar and other natural cheeses.

The microstructure of treated cheese samples was affected immediately by the HPP treatments, although the ripening process was not inhibited, as observed by a similar behavior of untreated and pressure-treated samples after ripening. High-pressure processing treatments of unripened cheese before shredding reduced the amount of crumbles, increased shred mean length, improved length uniformity, and enhanced surface smoothness. The visual and tactile characteristics of shreds obtained from pressuretreated stirred-curd Cheddar cheese coincided with properties deemed desirable by cheese processors (McMahon, personal communication, 2001) and showed that HPP treatment could entirely eliminate the ripening needed to get high quality shreds, yielding products of equal visual and tactile sensory attributes to those produced after 15 to $30 \mathrm{~d}$ of ripening.

Textural changes induced by pressure have been associated with the rupture of noncovalent interactions within the protein molecules (Messens et al., 1997), which causes protein denaturation, proteinprotein dissociation, and reaggregation of proteins. High-pressure processing treatment may fuse the particles together and strengthen internal binding forces, resulting in higher cohesiveness in treated cheeses compared with untreated cheeses (Nienaber et al.,
2000). Another effect associated with pressure treatments is the change in calcium equilibrium of the calcium-caseinate complex. The same researchers reported that under high pressure, calcium-casein associations were disrupted so that calcium migrated to the aqueous soluble phase. When the pressure was released, the equilibrium was reestablished, but the association between caseins was not restored to the conditions prior to the pressure treatment. It has been reported that with storage time the differences between pressure-treated and untreated samples decrease as reflected by TPA parameters (Law et al., 1998; Saldo et al., 2000b). In the present work, the differences between pressure-treated and untreated samples, as reflected by the hardness and cohesiveness TPA parameters, became smaller with storage. At d 13, most of the differences were no longer significant. Although hardness and cohesiveness were significantly modified by pressure treatments, structural reorientation and/or additional formation of bonds during ripening of pressurized Cheddar cheese led to similar characteristics at the end of storage compared with untreated control cheese. These results showed that initial modification of mechanical properties induced by HPP appear to be associated with the changes in sensory attributes detected by panelists. This initial modification did not affect the changes in mechanical properties that occur during ripening. These observations, along with other chemical measurements made in this study during cheese ripening, suggest that HPP-treated cheese appears to ripen to a product with characteristics similar to shredded cheese currently on the market. Therefore, the shredding of unripened pressure-treated cheese appears to have minimum negative consequences on product quality.

Scanning electron microscopy analysis confirmed visually that HPP changed the microstructure of Cheddar cheeses immediately after treatment, with changes associated with pressure level and pressurizing time. The reduction in the amount of crumbles as well as the increase in desirable physical properties such as mean length, size uniformity, and surface smoothness in the HPP-treated samples suggest that when pressure is applied, proteins may be partially denatured and form a more continuous structure matrix. This protein modification was beneficial for Cheddar cheese manufactured by stirred (this study) and milled (Serrano, 2003) technology, improving sensory attributes of cheese shredded before ripening without major modifications of mechanical properties after ripening, as determined by textural profile analysis (Table 2). The literature shows some results consistent with this study. For example, the reduction of crumbli- 
ness of goat cheese by high pressure has been reported by Saldo et al. (2000b). Capellas et al. (1997) reported that pressurization induced a modification in protein network in pressurized cheeses and associated these changes in protein matrices with changes in objective and subjective textural properties. Adhesiveness and tactile oiliness are both associated with the amount of oil on the surface of the cheese strips. In the study here reported, HPP-treated samples showed higher levels of these attributes after the first day, suggesting a larger amount of free fat probably caused by pressurization inducing a more continuous structure and leaving less available spaces to hold fat globules. This result could also reflect a modification in protein properties. Galazka et al. (1996) reported that high pressure reduced the emulsion properties of $\beta$-lactoglobulin due to pressure-induced protein structure modifications.

In conclusion, high-pressure treatments in terms of pressure level and pressurizing time modified the microstructure and texture properties of Cheddar cheeses. All pressure-treated cheeses immediately showed, as reflected by d 1 measurements, sensory attributes similar to those observed in untreated cheese ripened for $27 \mathrm{~d}$. Consequently, the shredded cheese manufacturing industry could shred the cheese immediately after cooling if the cheeses are treated with HPP. A moderate pressure treatment of $345 \mathrm{MPa}$ for 3 min was sufficient to induce the shredding characteristics of ripened cheeses, reducing storage and handling costs with expected savings of over (USD) $\$ 15 / 1000 \mathrm{lb}$ of cheese, considering only refrigerated storage savings (Farkas, personal communication, 2000) and not including additional savings by reducing steps in the handling of cheese blocks produced for shredding.

\section{ACKNOWLEDGMENTS}

This project is the result of international cooperation of researchers at Oregon State University, Universidad Autónoma de Querétaro, and Universidad Autónoma de Tamaulipas (México). The financial support from Dairy Management Inc. and the cooperation from Avure Technologies Inc. and Glanbia Foods Inc. are gratefully acknowledged. The contributions by E. Morales-Blancas at U. Austral de Chile in the preparation of the research funding request to Dairy Management Inc. are gratefully acknowledged.

\section{REFERENCES}

Association of Official Analytical Chemists. 2000. Official Methods of Analysis. 17th ed. AOAC, Gaithersburg, MD.
Anderson, T. F. 1951. Techniques for the preservation of threedimensional structure in preparing specimens for the electron microscope. Trans. NY Acad. Sci. 13:130-134.

Anderson, T. F. 1966. Electron microscopy of microorganisms. Pages 177-240 in Physical Techniques in Biological Research, Vol. IIIA. G. Oster and A. W. Pollister, eds. Academic Press, New York, NY.

Apostolopoulos, C., and R. J. Marshall. 1994. A quantitative method for the determination of shreddability of cheese. J. Food Qual. 17:115-128.

Bryant, A., Z. Ustunol, and J. Steffe. 1995. Texture of Cheddar cheese as influenced by fat reduction. J. Food Sci. 60:1217$1219,1236$.

Capellas, M., M. Mor-Mur, E. Sendra, and B. Guamis. 2001. Effect of high-pressure processing on physico-chemical characteristics of fresh goats' milk cheese (Mató). Int. Dairy J. 11:165-173.

Capellas, M., M. Mor-Mur, A. J. Trujillo, E. Sendra, and B. Guamis. 1997. Microstructure of high pressure treated cheese studied by confocal scanning light microscopy. Pages 391-394 in High Pressure Research in Bioscience and Biotechnology. K. Heremans, ed. Leuven University Press, Leuven, Belgium.

Casal, V., and R. Gomez. 1999. Effect of high pressure on the viability and enzymatic activity of mesophilic lactic acid bacteria isolated from caprine cheese. J. Dairy Sci. 82:1092-1098.

Charalambides, M. N., J. G. Williams, and S. Chakrabarti. 1995. A study of the influence of ageing on the mechanical properties of cheddar cheese. J. Mater. Sci. 30:3959-3967.

DeBault, L. E. 1973. A critical point drying technique for SEM of tissue culture cells grown on plastics substratum. Pages 317324 in Scanning Electron Microscopy. O. Johari, ed. IITRI, Chicago, IL.

Fox, P. F. 1988. Acceleration of cheese ripening-a review. Food Biotechnol. 2:133-185.

Galazka, V. B., E. Dickenson, and D. A. Ledward. 1996. Effects of high pressure on emulsifying behaviour of beta-lactoglobulin. Food Hydrocolloids. 10:213-219.

Guinee, T. P., M. A. E. Auty, C. Mullins, M. O. Corcoran, and E. O. Mulholland. 2000. Preliminary observations on effects of fat content and degree of fat emulsification on the structure-functional relationship of Cheddar-type cheese. J. Texture Stud. 31:645-663.

Hort, J., and G. LeGrys. 2000. Rheological models of Cheddar cheese texture and their application to maturation. J. Texture Stud. 31:1-24.

Jin, Z. T., and W. J. Harper. 2002. Effect of high pressure treatment (HPP) on microflora and ripening of Swiss cheese slurries. Milchwissenschaft 58:134-137.

Lagoueyte, N., J. Lablee, A. Lagaude, and B. Tarodo de La Fuente. 1994. Temperature affects microstructure of renneted milk gel. J. Food Sci. 59:956-959.

Law, J. R., J. Leaver, X. Felipe, V. Ferragut, R. Pla, and B. Guamis. 1998. Comparison of the effects of high pressure and thermal treatments on the casein micelles in goat's milk. J. Agric. Food Chem. 46:2523-2530.

Lawless, H. T., and H. Heymann. 1998. Sensory Evaluation of Food: Principles and Practices. Aspen Publishers, New York, NY.

Lee, C. H., E. M. Imoto, and C. Rha. 1978. Evaluation of cheese texture. J. Food Sci. 43:1600-1605.

Marshall, R. T. 1992. Standard Methods for the Examination of Dairy Products.16th ed. American Public Health Association, Washington, DC.

Meilgaard, M., G. V. Civille, and B. T. Carr. 1999. Sensory Evaluation Techniques, 3rd ed. CRC Press, Boca Raton, FL.

Messens, W., J. Estepar-Garcia, K. Dewettinck, and A. Huyghebaert. 1999. Proteolysis of high pressure treated Gouda cheese. Int. Dairy J. 9:775-782.

Messens, W., J. Van Camp, and A. Huyghebaert. 1997. The use of high pressure to modify the functionality of food proteins. Trends Food Sci. Technol. 8:107-112.

Messens, W., D. Van de Walle, J. Arevalo, K. Dewettinck, and A. Huyghebaert. 2000. Rheological properties of high pressure treated Gouda cheese. Int. Dairy J. 10:359-367. 
Metzger, L. E., and V. V. Mistry. 1995. A new approach using homogenization of cream in the manufacture of reduced fat Cheddar chesse. 2. Microstructure, fat globule distribution, and free oil. J. Dairy Sci. 78:1883-1895.

Nienaber, U., P. D. Courtney, and T. H. Shellhammer. 2000. Texture study of high pressure processed Cheddar cheese. IFT Annu. Mtg. Tech. Program Abstr., 225. (Abstr.)

Rosenberg, M., Z. Wang, S. L. Chuang, and C. F. Shoemaker. 1995. Viscoelastic property changes in Cheddar during ripening. J. Food Sci. 60:640-644.

Saldo, J., P. L. H. McSweeney, E. Sendra, A. L. Kelley, and B. Guamis. 2000a. Changes in curd acidification caused by high pressure treatment. Ir. J. Agric. Food Res. 39:169.

Saldo, J., E. Sendra, and B. Guamis. 2000b. High hydrostatic pressure for accelerating ripening of goat's milk cheese: Proteolysis and texture. J. Food Sci. 65:636-640.

Serrano, J. 2003. Efecto de altas presiones en la microestructura de quesos: Aplicación en el rallado de queso Cheddar para uso comercial. M.S. Thesis, Universidad Autónoma de Querétaro, Querétaro, México.
Smit, G., Z. Kruyswijk, A. H. Weerkamp, C. deJong, and R. Neeter. 1996. Screening for control of debittering properties of cheese. Pages 25-31 in Flavour Science: Recent Developments. A. J. Taylor and D. S. Notrtram, eds. Royal Society of Chemistry, Cambridge, UK.

Sutheerawattananonda, M., R. G. Fulcher, F. B. Martin, and E. D. Bastian. 1997. Fluorescence image analysis of process cheese manufactured with trisodium citrate and sodium chloride. J. Dairy Sci. 80:620-627.

Torres-Mora, M. A., A. Soeldner, E. Y. Ting, A. C. O. Hawes, G. D. Alemán, G. S. Bakski, W. R. McManus, C. L. Hansen, and J. A. Torres. 1996. Early microstructure changes in Cheddar cheese and effects of high pressure curd processing. IFT Annu. Mtg. Tech. Program Abstr. 9. (Abstr.)

Visser, S. 1993. Proteolytic enzymes and their relation to cheese ripening and flavor: An overview. J. Dairy Sci. 76:329-350.

Williams, D. 1997. Towers of the future. Dairy Ind. Int. 62:35-36.

Yang, J. 1999. Evaluation of hydrostatic pressure and storage effects on Cheddar cheese microstructure by thermal conductivity, differential scanning calorimetry and enzymatic proteolysis. M.S. Thesis, Oregon State Univ., Corvallis. 